\title{
The Effectiveness of Differentiated Instruction in Improving Bahraini EFL Secondary School Students in Reading Comprehension Skills
}

\author{
Ahmed Hussein Ahmad Eid Saleh \\ Mansoura University, Mansoura. Egypt \\ ahmedeid581@gmail.com
}

\begin{abstract}
Received : 2021-05-19
Revised : 2021-08-10

Accepted : 2021-08-19
\end{abstract}

ARTICLE HISTORY

\section{KEYWORDS}

$E F L$

Reading comprehension skills

Differentiated instruction

Secondary school students

\begin{abstract}
This study aimed at investigating the effectiveness of Differentiated Instruction (DI) in improving reading comprehension skills in the EFL secondary stage in Bahrain. The study adopted the quasi-experimental research design using thirtysix $2^{\text {nd }}$ year secondary students to be the study participants. The participants were divided into two groups: an experimental group that received the (DI) training and a control group that received the conventional way. A reading comprehension skills questionnaire and a pre-post EFL reading comprehension test was used in the study to collect the data. Results showed that the experimental group outperformed the control group in the EFL reading comprehension test. The findings indicated that the DI strategies helped to develop students' EFL reading comprehension skills. In addition, it revealed that using various materials for teaching reading comprehension skills to match students' different needs and abilities helped enhance their reading comprehension proficiency. A number of recommendations and suggestions for further research was presented.
\end{abstract}

\section{Introduction}

Foreign languages play an essential role in the process of communication among societies. They also contribute to developing them being aware of the differences among cultures. Because of the spread of democracy, education, technology, and the global village where we live, learning foreign languages became a necessity. and to deal with tourists and foreigners in banks, hotels, and foreign companies, learning foreign languages is fundamental to enhancing good communication skills. Therefore, learning English is necessary and considered the central core of communication between populations in a multicultural society full of foreigners and residents worldwide.

The main aim of teaching English as a foreign/second language in Bahrain, according to the Ministry of Education, is to provide the society with graduated citizens who are able either to use language skills fluently, in work or to conduct higher research in different fields or to be prepared to join one of the famous universities abroad. Thus, Bahrain's Ministry of Education always provides both teachers and students with the aims of teaching English as a foreign language. Therefore, there is a need for several methods and strategies to facilitate teaching
English to students to gain comprehension and fluency like native speakers. Baecher (2011) stated that implementing DI is the best way to achieve English language proficiency. Furthermore, Gibson (2013) agreed that DI nowadays is a vital tool to engage students and address the different needs of all students.

In the last few years, educationalists and researchers all over the world have become interested in the issue of 'Differentiated Instruction' as an instrument to help teachers observe individual student differences and to ensure all students' progress towards achieving the targeted learning outcomes (Ehrman, Leaver\& Oxford, (2003); Dahlman, Hoffman \& Brauhn 2008; Dornyei 2003; Valiande \& Koutselini 2009; Vibulphol 2004). This study is based on Vygotsky's (1962) sociocultural theory, constructivism, Tomlinson's (1999) theory of differentiated instruction, Gardner's multiple intelligences and the learning styles. Mavidou \& Kakana (2019) stated that there is an increasing interest in research for differentiated instruction as a vigorous way of supporting different students in their knowledge acquisition and skills while, on the other hand, it also breaks down the obstacles that prevent their distinctive abilities to show their maximum potential as students effectively. 
Murley (2010) reported that teachers carry the heavy responsibility of engaging to the immense learning varieties in their classrooms. These learning varieties are the reasons for many problems during teaching and assessments. Each student has his favourite learning styles and multiple intelligences. As a result, the "one for all" attitude to assessment is not reliable.

Effective learning is rarely to occur if all children in a classroom are doing the same thing. Teachers cannot satisfy students' different needs if every student is reading the same story and completing the same task. Academic needs are central. However, they are not the single needs students have. Students still require quality education to satisfy their educational requirements and varied needs. If teachers do not fulfill students' fundamental needs, core curriculum and teaching do not matter (Tomlinson \& McTighe, 2006).

A framework was set by Tomlinson (2001) for differentiating or tiering tasks. It was based on three main parts; content (the learning input presented by the teacher), process (the way the teacher has structured the activity), and product (what should students produce). Instructors have widely approved this framework to establish the many ways an activity can be adjusted for diverse students. However, other differentiated activities depend on students' multiple intelligences, learning styles or preferences rather than on levels of English language proficiency. According to Tomlinson (2000), differentiation includes the efforts of teachers to address variance among students in the classroom. Whenever a teacher reaches to an individual or small group to vary his or her teaching, the teacher is differentiating instruction.

Levy (2008) and Tomlinson (1999) added that differentiation could be practised in the content, process, product and learning environment. Content or "input" involves what teachers target to teach and how the students will achieve the level of knowledge and understanding. Tomlinson and Allan (2000) also mentioned that differentiating the content is to supply various ways to get the "facts, concepts, overviews or principles, attitudes, and skills related to the subject, as well as materials that represent those elements" (p. 7). Differentiating the process of teaching and learning or "how" the students get the information is another area of differentiation. To differentiate the learning process, selections would better be given in expressing the thoughts and facts (Benjamin, 2006; Knowles, 2009; Levy, 2008; and Tomlinson, 2001). In addition, the differentiated process has to match the content directly and help the students acquire the knowledge and skills (Tomlinson \& Strickland, 2005).

The product is the third area to applying differentiation. Levy (2008) declared that differentiating content, process, and product must be the ground of the students' strengths, needs, and learning styles and of the students' readiness, interests, and learning profiles. The students present what they have learned in the "output". Teachers can differentiate the products by supplying a diversity of things students utilise to prove what they have learned due to study (Knowles, 2009; Levy, 2008; and Tomlinson, 2001).

The last area to differentiate concerns the environment. Teachers can implement environment differentiation by modifying the classroom organisation to allow students to move between groups. The learning environment also plays a vital role in improving the students' achievement (Tomlinson, 2000). Therefore, a differentiated teacher is the one who builds his instruction mainly according to the student's differences, not on a preplanned fixed curriculum. The teachers should prepare and design lessons suitable to the students' interests and abilities using several ways of presenting the lessons and with different difficulties to match their students' diverse needs and learning profiles.

Many studies were conducted such as Li (2004); Fuchs et al. (2005); Habboush (2010); Al Udaini (2011); El Khateeb (2012); Ghorab (2013); Bahlool (2013); Chen \& Herron (2014); and Silva \& Cain (2015) which verified that there is a strong relationship between reading comprehension skills and academic success. However, students in Bahrain showed low achievement levels in reading fluency and reading comprehension. For this reason, students are rarely motivated, and their academic achievement is negatively affected. The researcher used some tools such as reading assessments to measure students' performance, checklists that documented students' reading skills, surveys that indicated students' attitudes towards reading, and the pilot study to ensure the problem's existence.

The primary purpose of reading is to comprehend the text being read, so if reading is without a purpose, comprehension does not occur. According to the researcher, developing reading skills is a way to understand a language better. Al Aila (2015) stated that reading is the most important skill a student can develop and that learning to read is an important skill every student must develop to be successful in school. In all subject matters, students have to be able to read and comprehend what they are reading. According to Cheung \& Slavin (2011), good reading skills are the foundation for a proper education.

In addition, Kuhail (2017) stated that the process of comprehending involves decoding the writer's words and then using background knowledge to construct an approximate understanding of the writer's message. According to Farrell (2009), we cannot teach all students to read using one method or combination methods. On the contrary, teachers should be aware of the multiple methods for teaching 
reading. Consequently, before selecting any valuable methods of teaching reading comprehension skills, they need to be aware of their students' current interests, learning profiles, strengths, challenges, and goals. As a result, the researcher believes that DI can be an appropriate approach for teaching reading.

Moats (2001) stated that many students who have a deficiency in their reading skills might have difficulty in other content areas, are less able to complete high school, and may struggle in higher education. Most of the students are not motivated to read. Reading in school is something unexciting, useless, or challenging for them. In addition, there was nearly no time spent reading outside of school. They became more interested in video games, television, mobile applications, sports, and entertaining activities instead of reading. The interest to enhance reading comprehension skills is unreachable if students are not involved in reading. Regarding the significance of differentiated instruction in today's different classrooms, the present study aimed at studying the effectiveness of differentiated instruction in improving the secondary EFL students' reading comprehension skills.

This study concentrated on the correlation between DI and reading comprehension and DI-based lesson plans to develop reading comprehension skills. Teachers and curricula designers in Bahrain and the Gulf area are in dire need of the results of this study to develop their strategies and curricula to match students' needs and varied abilities, and to narrow the gap between students' current reading comprehension level and the required performance. The more teachers and educationalists are aware of their students' needs and varied abilities, the more they are able to provide updated and differentiated methods and strategies that help improve students' performance. Furthermore, it studied the effect of using DI on specific reading comprehension skills such as (skimming a text, scanning a text, recognising the main idea of a reading text, recognising supporting details, differentiating between facts and opinions, identifying reference words and relating them to what they refer to, and inferring the meaning from the context). In addition, this study included more strategies and techniques than some of the other conducted studies, such as graphic organisers, tiered activities, KWL, learning stations, and learning contracts, to achieve accurate results. Moreover, the study intended to prove the relation between DI strategies and improving reading comprehension skills and provide the educationalists with a wellplanned program to help them apply suitable techniques that match their students' varied levels. Thus, the current study is characterised by its accurate results and varied techniques and strategies used. It also provides teachers and curricula designers with the required reading comprehension skills needed for secondary students in Bahrain.
The current study revealed that using DI effectively improved reading comprehension skills and helped students enhance their reading performance. It also proved the relation between applying DI strategies and techniques and improving selected reading comprehension skills. Finally, this is leading research to be carried out in Bahrain, including the Gulf Area, that helps with DI's teaching and comprehension.

\section{Method}

This research used a quasi-experimental study that examined the effectiveness of using Differentiated Instruction (DI) to enhance the reading comprehension skills of second-year secondary-stage students. Two intact groups from Al-Iman School in Bahrain were randomly selected: one served as the experimental group, and the other served as the control group. The experimental group was taught using DI, while the control group was taught using the regular strategy.

The study participants were thirty-six second-year "Al-Iman School "secondary students in Bahrain. Two intact classes were randomly selected (control and experimental), and each group consisted of eighteen students $(\mathrm{N}=18)$. The experimental group included one class of 18 students and was provided with DI. The other class of 18 students acted as the control group, and regular daily teaching was provided. A reading comprehension pre-test was given to the two groups to ensure that they were homogeneous before the DI was implemented.

To achieve the aims of the study, the researcher designed and used two tools:

1-A Reading Comprehension Skills Questionnaire (RCSQ) was used to identify the most appropriate reading comprehension skills for second-year secondary students. This questionnaire involved 14 items investigating the importance of each skill, which was emphasised in the present study, followed by three open-ended questions about the skills used in implementing the present study. The researcher derived the skills involved in the questionnaire in its initial form from different sources such as teachers' opinions, literature review concerning the area of reading comprehension skills and sub-skills, the teacher's book, a checklist of the suitable reading comprehension skills, and the jurors. To test the validity of the questionnaire, RCSQ was submitted to a group of jury of 22 EFL professors, teachers, and supervisors from different Arab countries to evaluate students' EFL reading comprehension skills performance. The jury was kindly asked to identify the degree of importance of each skill and the appropriateness of the skills suggested. In addition, they were asked to modify, exclude, or add reading comprehension skills as they consider fit. 
2-A Reading Comprehension Skills Test (RCST) was used to assess the two groups' reading performance before and after implementing the DI. The test consisted of one passage of six paragraphs that was prepared to measure seven reading comprehension skills (skim a text, scan a text, recognise the main idea of a reading text, recognise supporting details, differentiate between facts and opinions, identify reference words and relate them to what they refer to, and infer the meaning from the context). The pre-posttest consisted of 14 items; each group of questions measured one of the most critical seven reading comprehension skills. The test was presented to a group of jury members to determine whether the test items represent what they are supposed to represent and whether they are linguistically and scientifically appropriate. Some of the items and phrases were removed, others were added, and modifications were made according to the opinions of the jury members until the test was written in its final version. The researcher used the Paired Samples T-test (SPSS, Version 23) to measure mean, the standard deviation of scores, and the significance of the " $t$ " test for the differences independent and independent samples between both groups in the pre-post reading comprehension skills test and the overall score and the comprehension skills. It was also used to evaluate the effect size of the experimental treatment on enhancing the students' reading comprehension skills before and after the treatment.

\section{Findings}

Results of the study are reported in terms of the hypotheses.

\subsection{Verifying the Homogeneity of the Experimental and Control group}

The test aimed at identifying homogeneity of the experimental and control group in the reading comprehension skills test. Table 1 represents the results:

Table 3.1 The Mean Scores of the Experimental and Control Group in the pre- Reading Comprehension Skills Test

\begin{tabular}{|c|c|c|c|c|c|c|}
\hline Reading skills & The Pre-Test Measurements & $\mathbf{N}$ & Mean & SD & $\begin{array}{l}\text { Critical } \\
\text { value(t) }\end{array}$ & Sig \\
\hline \multirow[t]{2}{*}{ Skimming } & The Experimental Group & 18 & 2.11 & 1.45 & \multirow{2}{*}{3.08} & \multirow{2}{*}{0.001} \\
\hline & The Control Group & 18 & 3.56 & .40 & & \\
\hline \multirow[t]{2}{*}{ Scanning } & The Experimental Group & 18 & 3.61 & 1.45 & \multirow{2}{*}{1.78} & \multirow{2}{*}{0.001} \\
\hline & The Control Group & 18 & 3.78 & .84 & & \\
\hline \multirow{2}{*}{$\begin{array}{l}\text { Recognising the main } \\
\text { idea of a reading text }\end{array}$} & The Experimental Group & 18 & .75 & 1.09 & \multirow{2}{*}{4.61} & \multirow{2}{*}{0.000} \\
\hline & The Control Group & 18 & 1.88 & .11 & & \\
\hline \multirow{2}{*}{$\begin{array}{l}\text { Recognising supporting } \\
\text { details }\end{array}$} & The Experimental Group & 18 & 2.22 & 1.64 & \multirow{2}{*}{3.51} & \multirow{2}{*}{0.000} \\
\hline & The Control Group & 18 & 3.38 & .30 & & \\
\hline \multirow{2}{*}{$\begin{array}{l}\text { Identifying reference } \\
\text { words }\end{array}$} & The Experimental Group & 18 & 1.37 & 1.19 & \multirow{2}{*}{4.75} & \multirow{2}{*}{0.001} \\
\hline & The Control Group & 18 & 2.66 & .59 & & \\
\hline \multirow{2}{*}{$\begin{array}{l}\text { Inferring the meaning } \\
\text { from the context }\end{array}$} & The Experimental Group & 18 & 1.19 & 1.64 & \multirow{2}{*}{3.12} & \multirow{2}{*}{0.000} \\
\hline & The Control Group & 18 & 2.70 & .46 & & \\
\hline \multirow{2}{*}{$\begin{array}{l}\text { Differentiating between } \\
\text { facts and opinions }\end{array}$} & The Experimental Group & 18 & 1.00 & 1.45 & \multirow{2}{*}{4.07} & \multirow{2}{*}{0.001} \\
\hline & The Control Group & 18 & 3.00 & 1.82 & & \\
\hline \multirow[t]{2}{*}{ Total } & The Experimental Group & 18 & 14.83 & 6.45 & \multirow{2}{*}{6.20} & \multirow{2}{*}{0.001} \\
\hline & The Control Group & 18 & 20.30 & 4.16 & & \\
\hline
\end{tabular}

Table 3.1 shows that both the experimental and control group are homogeneous. There is no significant difference between the mean scores of both groups in the reading comprehension skills test.

\subsection{Verifying the First Hypothesis:}

The first hypothesis stated, "There is statistically significant difference at the 0.05 level between the mean score of the experimental group in the pre- measurement and the post measurement of the reading comprehension skills in favour of the post measurement".

\section{Testing the reading scores:}

In order to use Paired Samples T-test, data must meet the following requirements:

a) Continuous dependent variable (i.e., interval or ratio level) 
b) Related samples/groups (i.e., the subjects in each sample, or group, are the same. This means that the subjects in the first group are also in the second group.)

c) Random Selection of sample from the population

d) A normal distribution (approximately) of the difference between the paired values for 30 participants or fewer samples.

e) No outliers in the difference between the two related groups for samples of 30 participants or fewer.
The collected data from the pre/post-tests met all these criteria as follows:

a) The dependent variable is continuous as it is an interval.

b) The same students took each of the two tests.

c) Students were selected randomly.

d) SPSS calculated scores of students in the two tests to check their normality, as shown in table 1.

Table 3.2 Test of Normality for the reading pre/post-tests

\begin{tabular}{lccccccc}
\hline \multicolumn{1}{c}{ Group } & \multicolumn{3}{c}{ Kolmogorov-Smirnov ${ }^{\mathbf{a}}$} & \multicolumn{3}{c}{ Shapiro-Wilk } \\
\cline { 2 - 8 } & & Statistic & df & Sig. & Statistic & df & Sig. \\
\hline Pre & 2.00 & .135 & 18 & $.200^{*}$ & .946 & 18 & .362 \\
Post & 2.00 & .296 & 18 & $.200^{*}$ & .592 & 18 & .447 \\
\hline
\end{tabular}

*. This is a lower bound of the true significance.

\section{a. Lilliefors Significance Correction}

The significance of the pre-test is (0.200) according to Kolmogorov-Smirnov Test and (0.142) according to Shapiro-Wilk Test.

a) The significance of the post-test is (0.200) according to Kolmogorov-Smirnov Test and (0.447) according to Shapiro-Wilk Test.

b) The significance of each of the two tests is more remarkable than $(0.05)$, which means that the scores of the two tests follow the normal distribution.

c) There were no outliers in the scores of the students in the two tests.

In order to check the validity of this hypothesis, the researcher calculated students' reading scores in the pre/post-tests using Paired Samples T-test (SPSS, Version 23). Table 3.3 represents the results.

Table 3.3 Comparing the Reading Performance of the Experimental Group Students on the Reading Comprehension Skills Pre-Post Test

\begin{tabular}{|c|c|c|c|c|c|c|c|}
\hline \multirow[b]{2}{*}{ Skills } & \multirow[b]{2}{*}{$\mathbf{N}$} & \multicolumn{2}{|c|}{ Pre-Test } & \multicolumn{2}{|c|}{ Post Test } & \multirow{2}{*}{$\begin{array}{l}\text { Critical } \\
\text { value(t) }\end{array}$} & \multirow[b]{2}{*}{ Sig } \\
\hline & & Mean & SD & Mean & SD & & \\
\hline Skimming & 18 & 2.33 & 1.57 & 3.88 & .47 & 4.08 & 0.05 \\
\hline Scanning & 18 & 3.11 & 1.23 & 3.77 & .94 & 1.68 & 0.05 \\
\hline Recognising the main idea of a reading text & 18 & .88 & 1.02 & 2.00 & .23 & 4.61 & 0.05 \\
\hline Recognising supporting details & 18 & 2.88 & 1.23 & 3.83 & .38 & 3.79 & 0.05 \\
\hline Identifying reference words & 18 & 1.38 & 1.14 & 2.66 & .59 & 4.25 & 0.05 \\
\hline Inferring the meaning from the context & 18 & 2.11 & 1.45 & 3.77 & .64 & 4.12 & 0.05 \\
\hline Differentiating between facts and opinions & 18 & 1.11 & 1.23 & 3.38 & 1.28 & 5.07 & 0.05 \\
\hline Total & 18 & 13.83 & 5.45 & 23.30 & 3.16 & 7.20 & 0.05 \\
\hline
\end{tabular}

As shown in Table 3.3, there is a significant difference at 0.05 level between the scores of the experimental group students in the post-test $(\mathrm{M}=23.30, \mathrm{SD}=3.16)$ and in the pre-test $(\mathrm{M}=13.83$, $\mathrm{SD}=5.45) ; \mathrm{T}(17)=7.20, \mathrm{p}=0.000 .000$ This means that there are statistically significant differences between students' scores of the post-test and those of the pre-test, in favour of the post-test, which has the higher mean (23.30). These results show that the significant difference was in favour of the reading comprehension skills post-test, which means that using DI strategies effectively improved the 
experimental group's performance in the targeted reading comprehension skills. Moreover, these results revealed that there is a strong relationship between DI and improvement of comprehension. The more students are exposed to DI, the stronger their comprehension was. In addition, students who are taught through DI have done better in tests. The following figure (1) points out the differences between the mean scores of the pre and the post-test:

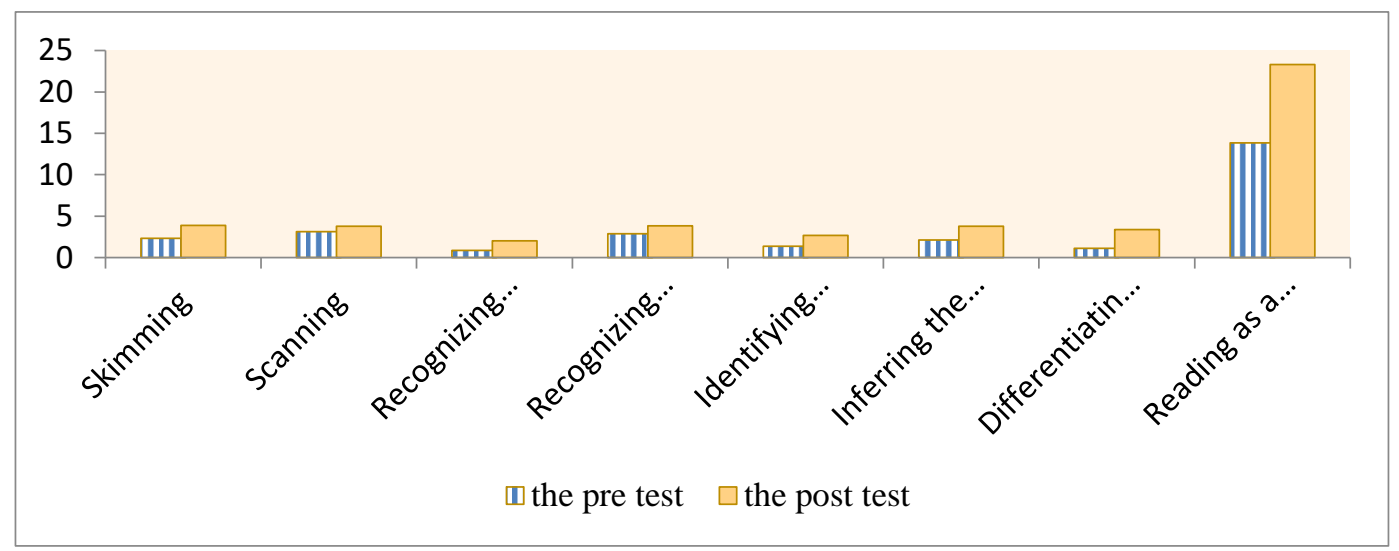

Figure 3.1. The Differences between Students' Scores of the Post-test and Those of the Pre-test

Figure 3.1 shows a difference between the scores of the experimental group in the pre and post-reading comprehension skills test in favour of the post-test. This result reveals that the experimental group students' reading comprehension skills improved after applying DI strategies through the treatment.

\subsection{Verifying the Second Hypothesis}

The second hypothesis stated, "there are statistically significant differences at the 0.05 level between the mean scores of the control and experimental group in the post administration of the reading comprehension skills and in each separate skill in favor of experimental group". The following table points out the results.

In order to check the validity of this hypothesis, the researcher calculated students' reading scores in the experimental and control group using Paired Samples T-test (SPSS, Version 23). Table 3.4 represents the results.

Table 3.4. The Results of Differences between the Mean Scores of the Control Group and the Experimental Group of the Reading Comprehension Skills

\begin{tabular}{|c|c|c|c|c|c|c|c|}
\hline \multirow[t]{2}{*}{ Skills } & \multirow[t]{2}{*}{$\mathbf{N}$} & \multicolumn{2}{|c|}{$\begin{array}{c}\text { The control } \\
\text { group }\end{array}$} & \multicolumn{2}{|c|}{$\begin{array}{c}\text { The } \\
\text { experimental } \\
\text { group }\end{array}$} & \multirow[t]{2}{*}{$\begin{array}{l}\text { Critical } \\
\text { value(t) }\end{array}$} & \multirow[t]{2}{*}{ Sig } \\
\hline & & Mean & SD & Mean & SD & & \\
\hline Skimming & 18 & 2.00 & 1.18 & 3.88 & .47 & 6.26 & 0.000 \\
\hline Scanning & 18 & 1.55 & 1.29 & 3.77 & .94 & 5.59 & 0.000 \\
\hline Recognising the main idea of a reading text & 18 & 2.00 & 0.97 & 2.00 & .22 & 0.15 & 0.00 \\
\hline Recognising supporting details & 18 & 2.22 & 1.21 & 3.83 & .38 & 5.36 & 0.00 \\
\hline Identifying reference words & 18 & 1.72 & 1.07 & 2.66 & .59 & 3.26 & 0.003 \\
\hline Inferring the meaning from the context & 18 & 2.33 & 1.41 & 3.77 & .64 & 3.94 & 0.000 \\
\hline Differentiating between facts and opinions & 18 & 1.50 & 1.33 & 3.38 & 1.28 & 4.31 & 0.000 \\
\hline Total & 18 & 13.33 & 5.39 & 23.30 & 3.16 & 6.76 & 0.000 \\
\hline
\end{tabular}

Note. Significant at 0.05

As shown in table, there is a significant difference between the scores of the students in the post-test of the experimental group $(\mathrm{M}=23.30, \mathrm{SD}=3.16)$ and the post-test of the control group ( $\mathrm{M}=13.33, \mathrm{SD}=5.39)$; $\mathrm{T}$ $(34)=6.76, p=0.05$. The significance of $\mathrm{T}$ is $(0.05)$, and this means that there are statistically significant differences between the mean scores of the control and experimental group in the post-test, in favour of the experimental group, which has the higher mean (23.30). These results show that the significant 
difference favoured the experimental group who outperformed the control group in the reading comprehension skills post-test. This proves that using DI strategies effectively improved the experimental group's reading comprehension in the targeted skills.
Moreover, these results revealed that there is a strong relationship between DI and improvement of comprehension. The DI program was the reason for the difference between the performance of the experimental and the control group.

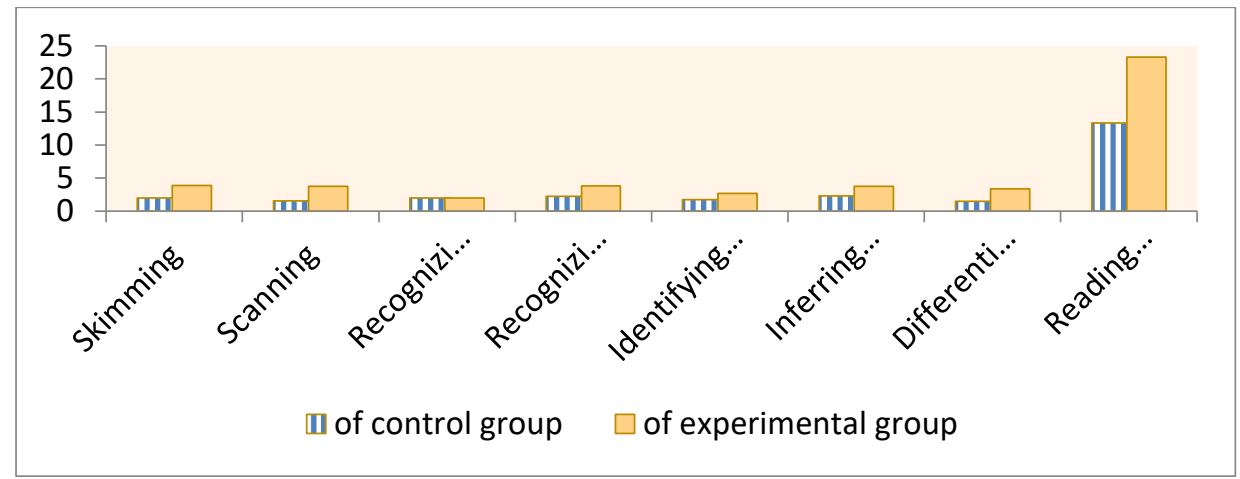

Figure 3.2 The Difference between the Control Group's Mean Scores and the Experimental Group of the Reading Comprehension Skills.

Figure 3.2 shows a difference between the experimental and the control group scores in the postreading comprehension skills test in favour of the experimental group. This result reveals that the experimental group students' reading comprehension skills improved after applying DI strategies through the treatment.

\section{4}

Reflective

Table 3.5 Questions to Consider

Questions to Consider
What did you learn in this course?
Why do you believe we are studying using DI?
Did you give your best effort on this most recent course?
Were the strategies, skills and procedures you used
effectively for improving your reading comprehension skills?
Did these activities help you learn more than others we have
done? Why?

If you could study using the DI strategy over, what would you do differently?

What resources do you have that can help you learn new material?

What class activities or assignments help you learn the most?

What do you believe the teacher could have done differently to help you learn easier?

What is one thing the teacher did for this course that you really liked?

Did you do an effective job of communicating my learning to others?

\section{Reflections}

I really feel like I learned many things with this course and (DI) strategy.

I think we are studying this way because every learner has different levels and interests.

I gave my best effort because it was interesting and useful to be with others and learn using DI strategies.

The strategies, skills and procedures used were effective for improving most of our reading comprehension skills.

Of course, we learnt through these strategies more than others did because it was challenging, and most activities cope with our abilities and interests.

I would select the most difficult exercises and activities to have more challenges.

There were a variety of reading resources that our teacher provided us.

Jigsaw- Think Pair Share and learning contracts.

I think the teacher could provide us with more sessions for more practice.

I really liked his sense of humour during teaching and his continuous feedback.

I can tell my teacher when I know something and help other students in my group. 
According to the students' answers to the given reflective log questions, students revealed an excellent appreciation for their improvement after applying for the DI strategies program. It copes with the second hypothesis, which stated statistically significant differences at the 0.05 level between the mean scores of the control and experimental group in the post administration of the reading comprehension skills and each skill in favour of the experimental group.

\section{Discussion}

DI is viewed as an essential factor that affects learning language in general and improves reading comprehension skills. The current study investigated the effectiveness of DI in improving reading comprehension skills, considering the different and varied abilities and profiles of students. In order to do so, the researcher raised the following questions;

a) What are the reading comprehension skills necessary for EFL secondary stage students in Bahrain?

b) What are the features of DI?

c) What is the effectiveness of using some selected DI strategies to improve reading comprehension skills for EFL secondary stage students in Bahrain?

\subsection{The Reading Comprehension Skills Necessary for EFL Secondary Stage Students in Bahrain}

Reading is the primary skill that helps students gain knowledge. It surges the ability of students to focus and develop critical thinking. Additionally, it develops positive feelings, satisfaction, and efficiency. Furthermore, it is an essential skill for students of English as it lets them progress in other academic fields. Without comprehension, reading is simply following words on a page from left to right while sounding them out. The words on the page have no meaning. Further, reading is an essential means by which new information is seized, and new language skills are acquired.

Moreover, many foreign language learners often have read as one of their most important goals in their language learning experience, and various educational aims served by topics help reading receive this particular focus. However, most EFL secondary students in Bahrain lack some reading comprehension skills such as skimming, scanning, identifying reference words, inferring meaning from context, differentiating between facts and opinions, and other skills. It is mainly because students consider reading an arduous task and need much effort. Furthermore, some students have some difficulties with language learning. Also, reading comprehension skills are neglected inside the EFL classroom as teachers give little attention to reading activities inside classrooms to improve students' reading comprehension skills.
The previous studies almost agreed that there were deficiencies in students' reading comprehension skills. Most reviewed studies investigated the primary reading comprehension skills, not the reading subskills. However, few previous studies were carried out in the Arab countries and the Gulf area. Nevertheless, the current study included more techniques than some of the other studies to achieve accurate results. The research used different approaches for differentiated instruction.

\subsection{The Features of DI}

DI is not an instructional strategy or teaching model. It is a way of thinking about teaching and learning which considers students' readiness, interest, and learning profile. It is a way of thinking that challenges how educators typically envision assessment, teaching, learning, classroom roles, time, and curriculum. When teachers differentiate their instruction, they consider student characteristics, readiness level, interest, and learning profile. These characteristics may be moulded by a learning style, intelligence preference or gender. Students' level of readiness, interests, and learning preferences can be accommodated by adapting the content, processes, and products. These adaptations encounter the varied individual needs of students and make them spend most of their time in school. Many students in the mixed-level classroom were generally not engaged enough in learning the language proficiently and lack most of their reading comprehension skills. The main reason for this is that most teachers cannot meet students' individual needs and follow one main whole classroom instruction most of the time.

In addition, many English language teachers in Bahrain are highly qualified and experienced. However, a significant number of teachers still use traditional instructions such as content memorising and teacher-centered instruction. They depend more and mainly on textbooks and cumulative assessment and overlook diversity (Souleles, 2013). Fairbairn \& Jones-Vo (2010) reported that there are many attempts to implement differentiation by many teachers in the English classroom, as they believe in its effectiveness. Then they find out that it is a very perplexing and overwhelming mission to do. According to Tomlinson \& Imbeau (2010), and in order to differentiate effectively, the teacher should fully understand the students' differences, learning styles, and abilities and the suitable approaches of DI and assessment. The current study suggested using some DI strategies to improve student's proficiency level and academic achievement. It also proved the effectiveness of DI in improving the reading comprehension skills required for EFL Bahraini secondary students.

\subsection{The Effectiveness of Using Some Selected DI Strategies in Improving The Reading Comprehension Skills}


Most of the previous studies investigated the effectiveness of some strategies at different school levels and grades in improving reading comprehension skills. Most of these researches concentrated on assessing the effect of learning approaches on the students ' reading comprehension. All these studies proved the effectiveness of these approaches and strategies in improving reading comprehension. Very few studies showed little or no gap between students who learned to utilise literacy approaches and students who studied using a conventional reading approach (Baier, 2005).

The current study revealed that there is a strong relationship between DI and improvement of comprehension. The more students are exposed to DI, the stronger their comprehension was. In addition, students who are taught through DI have done better in tests. These findings asserted that teaching by DI had a positive effect on reading comprehension skills. It is because students were educated according to their desires, expectations, and learning profile, according to those findings. Using Differentiated Instruction (DI) effectively improved Bahrain EFL secondary students' reading comprehension skills as the experimental group students outperformed the control group students in the post administration of the Reading Comprehension Skills test. This agreed with the findings of some previously mentioned studies. However, the present study results revealed more need to give more interest to differentiating reading comprehension activities so that no learner is left behind.

The high increase in the experimental group's post-administration scores was mainly due to engaging students in specific differentiated activities during the treatment, such as (tiered activities, learning centres, learning contracts, a jigsaw and graphic organisers). In addition, the DI activities helped the students enjoy learning and enhance their attitude towards reading according to their feedback on the reflective log. Further, most of the previous studies agreed on this issue. Participants made positive comments during the treatment implementation. For example, some of them agreed that practising DI activities helped them organise their ideas more quickly. Others said that through using the DI activities, they gathered these ideas and developed good reading comprehension skills for different texts. Furthermore, participants liked reading through DI activities more than just reading individually.

Therefore, DI was highly influential in enhancing students' reading comprehension skills and providing varied opportunities for interaction and discussion in the classroom throughout varied activities. In addition, all students agreed that they had a sense of responsibility and accomplishment. They did not hesitate to participate in answering some questions; shy students had positive participation in the classroom, they participated, and at the same time, they could maintain discipline. Moreover, DI positively impacted their interaction with each other that they learned in a teamwork environment. They were all winners due to some DI techniques used, such as think-pair-share and flexible grouping. In other words, the student learned enthusiastically, happily, and eagerly.

\section{Conclusion}

The current study concluded that improving reading comprehension skills among Bahrain secondary school students could be achieved using differentiated instruction. It presented evidence that using differentiated reading activities can motivate their reading efficiently. The study results were in agreement with some of the results of the previously mentioned studies.

It was apparent that the proposed differentiated instruction strategies and activities were fruitful in encouraging nearly all the students to participate in the reading process. This strategy helped them understand the reading text better and consequently answer the questions appropriately. They felt at ease in the different stages of the used strategy and while answering the reading comprehension questions, and eventually, they improved their reading comprehension skills.

\section{Recommendation}

The current study recommended that teachers shift from standard teaching methods to differentiated teaching based on the genuine involvement of the students in the learning process, enriching the curriculum with differentiated teaching that enhances the use of English by students both within and outside school. They also should understand the individual differences and learning styles of the students when selecting teaching activities. Supervisors should conduct training programs that improve and develop the performance of English teachers in teaching reading comprehension skills and carry out secondary grade model lessons to show teachers how to teach reading using DI. In addition, the Ministry of Education has to include new methods and strategies in teaching English depending on differentiated instruction and provide curricula that are more effective for secondary stage students equipped with current teaching and learning trends that match the students' varied learning profiles and levels

The study also recommended for the faculty of education to provide the faculty-student teachers with the required strategies and methods that enable them to differentiate their instruction to respond to the differences among students and cooperate with the syllabus designers and Ministry of Education to develop the curricula to cope with the $21^{\text {st }}$-century skills and differentiated instruction strategy. 


\section{Suggestion for Further Research}

In order to gain a more comprehensive understanding of this topic, further research may be considered, including the following:

a) Evaluation of Bahrain Secondary stage textbooks from the perspective of teachers and supervisors to identify how and what to differentiate.

b) Conducting a study on the effect of DI on improving other language skills.

c) Evaluating the teachers' attitudes towards applying DI and its impact on students' academic achievement.

d) Investigating the effectiveness of some DI strategies on improving reading comprehension skills and students' reading fluency in other school stages.

\section{References}

Al Aila, M. Z (2015). Effectiveness of Using Scaffolding Strategy on Developing Seventh Graders' Reading Comprehension Skills. [Master's thesis, Islamic universityGaza]. http://hdl.handle.net/20.500.12358/18549

Al Udaini, A. A (2011). The Effect of a Computerized Program on Developing 9th Graders' Reading Comprehension Skills and their Attitudes towards Reading in Palestine. [Master's thesis, Islamic university-Gaza]. http://hdl.handle.net/20.500.12358/17783

Baecher, L. H. (2011). Differentiated instruction for English language learners: Strategies for the secondary English teacher. The Wisconsin English Journal, 53(2), 64-73.

Bahlool, A. A (2013). The Effect of Differentiated Instruction Strategy on Developing Ninth Graders' English Reading Comprehension Skills at Gaza UNRWA Schools. [Master's thesis, Islamic university-Gaza]. .http://hdl.handle.net/20.500.12358/17649

Baier, R. (2005). Reading comprehension and reading strategies. [Master's thesis, University of Wisconsin-Stout, Menomonie, United States of America].

https://core.ac.uk/download/pdf/5066651.pdf

Benjamin, A. (2006). Valuing differentiated instruction. The Education Digest, 72(1), 5759.

Byrd, D. R. (2012). Differentiating Instruction and Assessment for English Language Learners: A Guide for K 12 Teachers. TESOL quarterly: a journal for teachers of English to speakers of other languages and of standard English as a second dialect, 46(2), 425-427.
Chen, S., \& Herron, S. S. (2014). Going against the grain: Should differentiated instruction be a normal component of professional development. International Journal of Technology in Teaching and Learning, 10(1), 14-34.

Cheung, A. C., \& Slavin, R. E. (2011). The Effectiveness of Education Technology for Enhancing Reading Achievement: A MetaAnalysis. Center for research and reform in education. https://eric.ed.gov/?id=ED527572

Dahlman, A., Hoffman, P., \& Brauhn, S. (2008). Classroom strategies and tools for differentiating instruction in the ESL classroom MInneTESOL/WITESOL Journal. 25(12). 1-23

Dörnyei, Z. (2003). Attitudes, orientations, and motivations in language learning: Advances in theory, research, and applications. Language learning, 53(S1), 3-32. https://doi.org/10.1111/1467-9922.53222

Ehrman, M. E., Leaver, B. L., \& Oxford, R. L. (2003). A brief overview of individual differences in second language learning. System, 31(3), 313-330. https://doi.org/10.1016/S0346-251X(03)00045$\underline{9}$

El Khateeb, E. R (2012). The Impact of Using WebQuests on the Palestinian Seventh Graders' English Reading Comprehension Skills and their Attitudes towards WebQuest. [Master's thesis, Islamic universityGaza]. http://hdl.handle.net/20.500.12358/17955

Farrell, T. S. C., \& Farrell, T. S. (2009). Teaching reading to English language learners: A reflective guide. Corwin press.

Fuchs, D., \& Fuchs, L. S. (2005). Peer-assisted learning strategies: Promoting word recognition, fluency, and reading comprehension in young children. The Journal of Special Education, 39(1), 34-44. https://doi.org/10.1177/0022466905039001040 $\underline{1}$

Ghorab, M. A. R. (2013). A Suggested Program Based on Picture Reading Strategy to Improve English Reading Comprehension Skills among Seventh Graders in Palestine. [Master's thesis, Islamic university-Gaza]. http://hdl.handle.net/20.500.12358/17655

Gibson, L. (2013), Differentiated Instruction and Students with Learning Disabilities. Advances in Special Education, 24. 161-183. https://doi.org/10.1108/S02704013(2013)0000024012 
Haboush, Z. Y. (2010). The Effectiveness of Using a Program Based on Multiple Intelligences Theory on Eighth Graders' English Reading Comprehension Skills. [Master's thesis, Islamic university-Gaza]

.https://iugspace.iugaza.edu.ps/handle/20.500.1 2358/17593.

Knowles, L. (2009). Differentiated Instruction in Reading: Easier than It Looks! School Library Media Activities Monthly, 25(5), 26-28.

Kuhail, A. A. (2017). The Effectiveness of Using Interactive Digital Videos on Developing Sixth Graders' English Reading Skills and Vocabulary learning and Retention. [Master's thesis, Islamic university-Gaza]. http://hdl.handle.net/20.500.12358/18553

Levy, H. M. (2008). Meeting the needs of all students through DI: Helping every child reach and exceed standards. The Clearing House: A Journal of Educational Strategies, Issues, and Ideas, 81(4), 161-164.

Li, S. (2004). Equate-to-differentiate approach: An application in binary choice under uncertainty. Central European Journal of Operations Research, 12(3), 269-294.

Mavidou, A., \& Kakana, D. (2019). Differentiated instruction in practice: Curriculum adjustments in kindergarten. Creative Education, 10(3), 535-554.

Moats, L. C. (2001). When older students can't read. Educational Leadership, 58(6), 36-41.

Murley, R. M. (2010). Toward improved inclusion practices: A program evaluation of differentiated instruction in three sixth-grade classes. University of Phoenix.

Silva, M., \& Cain, K. (2015). The relations between lower and higher-level comprehension skills and their role in prediction of early reading comprehension. Journal of Educational Psychology, 107(2), 321.

Souleles, N. (2013). The evolution of art and design pedagogies in England: Influences of the past, challenges for the future. International Journal of Art \& Design Education, 32(2), 243-255.

Tomlinson, C. A. (1999). Mapping a route toward differentiated instruction. Educational leadership, 57(2), 12-17.

Tomlinson, C. A. (2000). Reconcilable differences: Standards-based teaching and differentiation. Educational leadership, 58(1), 6-13

Tomlinson, C. A. (2001). How to differentiate instruction in mixed-ability classrooms $\left(2^{\text {nd }}\right.$ ed)). ASCD.
Tomlinson, C. A., \& Allan, S. D. (2000). Leadership for differentiating schools and classrooms. ASCD.

Tomlinson, C. A., \& Imbeau, M. B. (2010). Leading and managing a differentiated classroom. ASCD.

Tomlinson, C. A., \& McTighe, J. (2006). Integrating differentiated instruction \& understanding by design: Connecting content and kids. ASCD.

Tomlinson, C. A., \& Strickland, C. A. (2005). Differentiation in practice: A resource guide for differentiating curriculum, grades. ASCD.

Valiande, S., \& Koutselini, M. I. (2009, June). Application and evaluation of differentiation instruction in mixed ability classrooms. In $4^{\text {th }}$ Hellenic Observatory PhD Symposium (pp. 2526). London, UK: LSE, London School of Economics.

Vibulphol, J. (2004). Beliefs about language learning and teaching approaches of pre-service EFL teachers in Thailand [Doctoral dissertation, Oklahoma State University]. https://www.culi.chula.ac.th/publicationsonline /files/journal/XEfYjThu31604.pdf 